\title{
Castor oil based polyurethane adhesive content on OSSB produced with soybean straw
}

\author{
Efeito do teor de adesivo poliuretano à base de óleo de \\ mamona em painéis OSSB de palha de soja
}

\begin{abstract}
João Vitor Felippe Silva
Maria Fernanda Felippe Silva

Bruno Santos Ferreira

Juliano Fiorelli

André Luis Christoforo

Cristiane Inácio de Campos

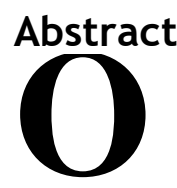

riented Structural Straw Board (OSSB) panels are composites made from straw originally from agricultural residues and nonformaldehyde based adhesive, whose main application is for construction as a closing and ceiling material. The objective of this study was to evaluate the effect of the polyurethane adhesive content on physical and mechanical properties of OSSB produced with locally available $\mathrm{SbS}$ (soybean straw). Four castor oil based polyurethane ratios $(6 \%, 9 \%, 12 \%$ and $15 \%$, by mass of the $\mathrm{SbS}$ ) were tested. OSSB was evaluated according to European standards for wood-based composites; also, a physical and chemical characterization of the SbS was performed. SbS has an irregular shape, which reduced the OSSB mechanical performance due to the low densification of the composite and the development of transversal cracks on the SbS after the OSSB manufacturing process. The static bending and thickness swelling performance of SbS OSSB was not improved by the increase of polyurethane

1João Vitor Felippe Silva 'Universidade Estadual Paulista Guaratinguetá - SP - Brasil

${ }^{2}$ Maria Fernanda Felippe Silva 2Universidade Estadual Paulista Itapeva - SP - Brasil

${ }^{3}$ Bruno Santos Ferreira ${ }^{3}$ Universidade Estadual Paulista Itapeva - SP - Brasil

${ }^{4}$ Juliano Fiorelli ${ }^{4}$ Universidade de São Paulo Pirassununga - SP - Brasil

${ }^{5}$ André Luis Christoforo ${ }^{5}$ Universidade Federal de São Carlos São Carlos - SP - Brasil

${ }^{6}$ Cristiane Inácio de Campos ${ }^{6}$ Universidade Estadual Paulista Itapeva - SP - Brasil

Recebido em 09/08/19 Aceito em 28/04/20 adhesive content. SbS low ash content and neutral $\mathrm{pH}$ extractives indicates that probably its chemical properties should not affect the setting of the adhesive.

Keywords: Glycine max L. Agricultural residue. Structural composite.

\section{Resumo}

Painéis OSSB (Oriented Structural Straw Board) são compósitos produzidos com palha proveniente de resíduos agrícolas e utilizando de adesivo sem formaldeído, cuja principal aplicação se volta para a construção civil como material de fechamento e forros. Este trabalho teve como objetivo avaliar o efeito do teor de poliuretano no adesivo sobre propriedades físicas e mecânicas do OSSB produzido com SbS (palha de soja) localmente disponível. Quatro composições de poliuretano à base de óleo de mamona (6\%, 9\%, 12\% e $15 \%$, em relação à massa de palha) foram testadas. Painéis OSSB foram avaliados de acordo com os padrões europeus para compósitos à base de madeira; também, uma caracterização física e química da $S b S$ foi realizada. A SbS possui formato irregular, o que reduziu o desempenho mecânico do OSSB devido à baixa densificação do compósito e ao desenvolvimento de trincas transversais na SbS após o processo de fabricação do compósito. $O$ desempenho em testes de flexão estática e inchamento de espessura do OSSB não foi melhorado pelo aumento do teor de adesivo de poliuretano. A SbS apresentou baixo teor de cinzas (menos que 4.3\%) e pH neutro, isto indica que estas propriedades químicas provavelmente não afetaram na cura do adesivo.

Palavras-chave: Glycine max L. Resíduo agrícola. Compósito estrutural.
\end{abstract}

SILVA, J. V. F.; SILVA, M. F. F.; FERREIRA; B. S.; FIORELLI, J.; CHRISTOFORO, A. L.; CAMPOS, C. I. de. Castor oil based polyurethane adhesive content on OSSB produced with soybean straw. Ambiente Construído, Porto Alegre, v. 21, n. 1, p. 23-36, jan./mar. 2021. 


\section{Introduction}

According to the USDA (UNITED..., 2019), more than 360 million metric tons of soybean oilseeds were harvested worldwide in 2018/2019, and Brazil is the second main soybean producer in the world, after the United States. Lal (2005) and Krisnawati and Adie (2015) determined values ranging from 0.8 to 2.6 of soybean dry straw to grain ratio, demonstrating the large availability of this residue.

Agricultural residues are often considered a problem for farmers due to their low monetary return, but they can be viewed as an economic opportunity, especially for developing countries where they can have a positive impact (ADEL et al., 2016). Some residues (e.g. wheat straw, rice straw and rice husk) receive interest due to their low cost, great availability, reduction of environmental pollution and large number of natural polymers in their composition (ARGENTO et al., 2019; LIMA et al., 2019).

Barbu, Reh and Çavdar (2017) indicate that the production of composites with agricultural residues is considered attractive, especially due to the increase in the price of wood as a raw material. According to Väisänen et al. (2016) it is required that these products do not present inferior performance in comparison to currently available wood-based composites, otherwise the selection of the agricultural residue as a raw material will not happen.

Studies applying SbS (soybean straw) residues in the production of composites have been developed (REINPRECHT et al., 2015; SITZ; BAJWA, 2015; SHAO; YANG; JIANG, 2016; MARTELLI-TOSI et al., 2017) and showed positive results in comparison to traditional materials (e.g. timber, plywood and fiberboards), although these composites are classified as non-structural according to EN 300 standard (EUROPEAN..., 2006).

It is also important to note that there have not been studies performed to evaluate the thermal conductivity of $\mathrm{SbS}$ based composites, even though this property is used to determinate heat transfer and insulation of building constructions, such as cladding, roughing and flooring (TRIPATHI; RICE, 2017; ÇAVUŞ et al., 2019).

This paper aimed to analyze the feasibility of producing a structural composite applying locally available $\mathrm{SbS}$, in order to increase its economic value.

OSSB is a commercially available composite with structural performance that uses rice or wheat straw and had its first manufacturing plant starting operations in China in 2009 (HAN et al., 2012). The straw is split longitudinally prior to the production of the board due to the action of two grooved rollers with different tangential speed, so the binder is allowed to have contact with the inside of the split straw (BACH; DOMIER; HOLOWACH, 1999).

OSSB is composed of three layers of straw that are oriented perpendicular to each other, offering better dimensional stability and mechanical performance in both directions of the plane (MARRA, 1992); this same principle is applied to wood-based composites, such as plywood, CLT (Cross Laminated Timber) and OSB (Oriented Strand Board). Image analysis is used in order to evaluate the straw orientation and layers thickness, due to the need of better characterizing and understanding this composite structure.

Another feature of OSSB is the use of formaldehyde-free adhesive (i.e. p-MDI resin) in its composition, due to a better adhesion to straw in general (BACH; DOMIER; HOLOWACH, 1999; HAN et al., 2012; CHENG; HAN; FANG, 2013). Also, the limits of formaldehyde release of adhesives applied to lignocellulosic composites are under focus due to society's demand for more ecological processes and because its contribution to poor indoor air quality (STEFANOWSKI; CURLING; ORMONDROYD, 2017; WANG et al., 2018).

Polyurethane is another type of formaldehyde-free adhesive (polyurethane based) that has a wide range of applications in industry (TANG et al., 2008). This binder has been substantially investigated as a replacement of conventional adhesives in wood-based and other lignocellulosic composites (MERLINI; SOLDI; BARRA, 2011; FIORELLI et al., 2012, 2013; BERTOLINI et al., 2013; VALARELLI et al., 2014; CHEN; TAI, 2018; NASCIMENTO et al., 2018; VARANDA et al., 2018; FERRO et al., 2019; MACEDO et al., 2019; SHIROSAKI et al., 2019). The use of castor oil polyurethane adhesive in the composition SbS OSSB in this paper is justified due the abundance of the Ricinus communis L. plant in Brazil, whose seeds are used for the production of the resin (CANGEMI et al., 2006).

The goal of this study was to evaluate the potential of using $\mathrm{SbS}$ and polyurethane adhesive for producing composites with structural performance. 


\section{Methods}

$\mathrm{SbS}$ was collected two days after the soybean harvest in the region of Itapeva-SP, in Brazil. The soybean clone used was M5917IPRO in a clayey soil with 14 plants per linear meter. SbS was physically and chemically characterized prior to the production of the strawboard. A commercially available polyurethane adhesive $\left(\mathrm{KEHL}^{\circledR}\right)$ with $100 \%$ solid content was used, which was obtained by reaction of polymeric isocyanate with castor oil as a polyol in the mass ratio of 50:50.

\section{SbS physical characterization}

Straw density was determined according to the method described by Lam et al. (2008). SbS was considered a hollow cylinder and had its mass measured with a laboratory scale and dimensions - diameter, wall thickness and length - measured with a caliper in order to determine the straw volume and density, as shown on Equation 1:

S.D. $=\frac{M i}{\left(d \cdot t-t^{2}\right) \cdot \pi \cdot l} \cdot 10^{6}$

Where:

S.D. = straw bulk-density, in $\mathrm{kg} \cdot \mathrm{m}^{-3}$;

$M i=$ mass of the internode section, in $\mathrm{g}$;

$d=$ internode section diameter, in $\mathrm{mm}$;

$t=$ wall thickness of the internode section, in $\mathrm{mm}$; and

$l=$ length of the internode, in $\mathrm{mm}$.

SbS had its mass determined in a laboratory scale before and after being dried in an air-forced oven at 103 ${ }^{\circ} \mathrm{C}$ for 24 hrs. Straw moisture content (S.M.C.) was determined using the initial mass $\left(M_{1}\right)$ and the dried mass $\left(M_{2}\right)$, as described at Equation 2:

S.M.C. $=\frac{\left(M_{1}-M_{2}\right)}{M_{2}} \cdot 100$

Eq. 2

Where:

S.M.C. = straw moisture content, in \%;

$M_{1}=$ initial mass, in $\mathrm{g}$; and

$M_{2}=$ dried mass, in $\mathrm{g}$.

$\mathrm{SbS}$ is composed of the plant's stem and petioles, each of them presenting different dimensions. A comparison of number of internodes, average diameter, average wall thickness, average internode length and total length for both parts of the soybean plant was carried out.

\section{SbS chemical characterization}

SbS was initially reduced to particles using a hammer mill (TE-650, TECNAL. Brazil) until reaching dimensions of 40- to 60- mesh. Total Extractive Content (T.E.C.) and Hot Water Extractive Content (H.W.E.C.) were determined according to TAPPI 204 method. T.E.C. was determined as the difference between masses of the particles before $(\mathrm{mb})$ and after $(\mathrm{ma})$ a three stage extraction process, as shown in Equation 3:

T.E.C. $=\frac{(m b-m a)}{m a} \cdot 100$

Where:

T.E.C. = total extractive content, in \%;

$m b=$ mass before extraction, in $\mathrm{g}$; and

$m a=$ mass after extraction, in $\mathrm{g}$.

The first stage of extraction used 1/3 ethanol and $2 / 3$ benzene solution for $5 \mathrm{~h}$, the second stage used ethanol solution for $4 \mathrm{~h}$, and in the last stage the extraction used boiling water for $1 \mathrm{~h}$. H.W.E.C. followed the same 
principle, except that there was only one stage of extraction in boiling water for $3 \mathrm{~h}$. The resulting solution of the H.W.E.C. test had its $\mathrm{pH}$ measured.

Ash Content (A.C.) of SbS was determined according to EN 1755-01 (AMERICAN..., 2015) method. Two grams samples were heated in a laboratory furnace at $575{ }^{\circ} \mathrm{C}$ for $3 \mathrm{~h}$. A.C. was considered as the ratio between the sample mass after three hours at the furnace $(m f)$ and initial mass $(m i)$, as described in Equation 4:

A.C. $=\frac{m f}{m i} \cdot 100$

Where:

A.C. = ash content, in \%;

$m f=$ final mass, in $\mathrm{g} ;$ and

$m i=$ initial mass, in $\mathrm{g}$.

\section{OSSB production process}

OSSB was produced in laboratory scale according to the method described by Bach, Domier and Holowach (1999) and Shirosaki et al. (2019). SbS was manually split along its main axis to expose its inner regions, and then was dried in a laboratory oven at $103{ }^{\circ} \mathrm{C}$ for $24 \mathrm{~h}$ before the production of the boards. Dried split $\mathrm{SbS}$ was mixed with castor oil based polyurethane adhesive and the mattress was formed inside a retaining square box with $0.42 \mathrm{~m}$ side.

The mattress was pressed in room temperature for $10 \mathrm{~min}$ with pressure of $0.4 \mathrm{MPa}$. Then the board was pressed in a heated hydraulic press (PHH 80T, Hidralmac. Brazil) at $100{ }^{\circ} \mathrm{C}$ in three cycles of $180 \mathrm{~s}$ (there was a pressure release of $3 \mathrm{~s}$ between cycles) with pressure of $4 \mathrm{MPa}$, following the Ferreira, Silva and Campos (2017) method. The board had a nominal thickness of $15 \mathrm{~mm}$ and target density of $650 \mathrm{~kg} \mathrm{~m} \mathrm{~m}^{-3}$ and was composed of three perpendicular layers in the proportion of $30: 40: 30$ by mass. Each layer had the straw oriented longitudinally in a preferential direction. Four adhesive contents (ranging from $6 \%$ to $15 \%$ in relation to the dried straw mass) were tested, in order to determine its optimal amount in the composition of OSSB.

\section{OSSB physical characterization}

The determination of density of the boards was based on EN 323 standard (EUROPEAN ...1993a). Specimens (with nominal dimensions of $0.05 \mathrm{~m} \mathrm{x} 0.05 \mathrm{~m} \mathrm{x} 0.015 \mathrm{~m}$ ) had their length, width and thickness measured with a caliper and mass measured with a laboratory scale. Density was calculated according to Equation 5:

$D=\frac{m}{l \cdot w \cdot t} \cdot 10^{6}$

Where:

$D=$ density, in $\mathrm{kg} \cdot \mathrm{m}^{-3}$;

$m=$ mass of the specimens, in $\mathrm{g}$;

$l=$ length of the specimens, in $\mathrm{mm}$;

$w=$ width of the specimens, in $\mathrm{mm}$; and

$t=$ thickness of the specimens, in mm.

Moisture content (M.C.) determination method was based on EN 322 standard (EUROPEAN..., 1993b). Specimens with at least $0.02 \mathrm{~kg}$ had their initial mass $(\mathrm{mi})$ and final mass $(\mathrm{mf})$ measured with a precision scale. The final mass was defined as the mass of the specimen dried in a laboratory oven at $103{ }^{\circ} \mathrm{C}$ until reaching a constant value - less than $0.1 \%$ variation between consecutive measurements taken every six hours. The moisture content of the boards was defined according to Equation 6:

M.C. $=\frac{(m i-m f)}{m f} \cdot 100$

Eq. 6

Where:

M.C. = moisture content, in \%; 
$m i=$ initial mass, in $\mathrm{g} ;$ and

$m f=$ dried mass, in $\mathrm{g}$.

Thickness Swelling (T.S.) after immersion in water for 2 and $24 \mathrm{~h}$ were determined according to EN 317 standard (EUROPEAN..., 1993c). Square specimens $(0.05 \mathrm{~m}$ x $0.05 \mathrm{~m})$ had their thickness measured with a caliper before $(t i)$ and after $(t f)$ immersion in water at room temperature and neutral $\mathrm{pH}$ for $2 \mathrm{~h}$ and $24 \mathrm{~h}$, as shown in Equation 7:

T.S. $=\frac{(t f-t i)}{t i} \cdot 100$

Where:

T.S. = straw moisture content, in \%;

$t i=$ initial thickness, in $\mathrm{mm}$; and

$t f=$ final thickness, in $\mathrm{mm}$.

The optical micrographs of the specimens were taken by a Lupe (M80, Leica. Brazil) with a coupled camera (DFC295, Leica. Brazil) connected to a computer using Leica QWin Standard V 3.5.1 software (2008) for image processing. Conductivity tests were performed with a Thermal Properties Analyzer (KD2 Pro, Decagon Devises, Inc.) in an acclimatized chamber (SM-3.5S, THERMOTRON) at $20^{\circ} \mathrm{C}$.

\section{OSSB mechanical characterization}

Mechanical tests were performed using a universal testing machine (DL 30000, EMIC. Brazil). The threepoint bending test was based on EN 310 standard (EUROPEAN..., 1993d), where specimens (350 mm x 50 $\mathrm{mm}$ ) were tested using a span of $300 \mathrm{~mm}$ with a crosshead speed of $7 \mathrm{~mm} / \mathrm{min}$. MOE and MOR were determined according to Equations 8 and 9, respectively.

MOE $=\frac{l^{3} \cdot\left(P_{2}-P_{1}\right)}{4 \cdot w \cdot t^{3} \cdot\left(a_{2}-a_{1}\right)}$

Where:

$M O E=$ Modulus of elasticity, in MPa;

$l=$ length of span, in $\mathrm{mm}$;

$\left(P_{2}-P_{1}\right)=$ is the increment of load on the load-deflection curve, where $\mathrm{P}_{2}$ was approximately $40 \%$ and $\mathrm{P}_{1}$ $10 \%$ of the maximum load, in $\mathrm{N}$;

$w=$ width of the specimens, in $\mathrm{mm}$;

$t=$ thickness of the specimens, in $\mathrm{mm}$; and

$\left(a_{2}-a_{1}\right)=$ the increment in deflection due to $(P 2-P 1)$ in the load-deflection curve.

MOR $=\frac{3 \cdot P_{\max } \cdot l}{2 \cdot w \cdot t^{2}}$

Where:

$M O R=$ modulus of rupture, in $\mathrm{MPa}$;

$P_{\max }=$ maximum load, in N;

$l=$ length of the span, in $\mathrm{mm}$;

$w=$ width of the specimens, in $\mathrm{mm}$; and

$t=$ thickness of the specimens, in $\mathrm{mm}$.

Internal Bonding (IB) test was performed according to EN 319 standard (EUROPEAN..., 1993e). Square specimens $(50 \mathrm{~mm} \times 50 \mathrm{~mm})$ were bonded to wood braces using fast bonding contact adhesive. Crosshead speed of $0.5 \mathrm{~mm} / \mathrm{min}$ was applied until failure of the samples, and $I B$ was determined according to Equation 10.

$I \cdot B .=\frac{P_{\max }}{l \cdot w}$

Eq. 10

Where: 
$I B=$ Internal bond, in $\mathrm{MPa}$;

$P_{\max }=$ maximum load, in $\mathrm{N}$;

$w=$ width of the specimens, in $\mathrm{mm}$; and

$l=$ length of the specimens, in $\mathrm{mm}$.

Resistance to screw withdrawal was performed according to EN 320 standard (EUROPEAN..., 2011), as seen in Figure 1. Specimens $(75 \mathrm{~mm}$ x $75 \mathrm{~mm}$ ) had their edge and face screw withdrawal strength measured by the maximum tension applied before the failure of the sample.

\section{Statistical analysis}

The average interval of confidence for the physical and chemical evaluated properties of the SbS was determined, tested with $\mathrm{p}<0.05$. The factor studied was the polyurethane adhesive content in OSSB production, totaling four treatments with six replications for each test. The Tukey test was performed by ANOVA analysis, tested with $\mathrm{p}<0.05$. The software used to interpret the results was $\mathrm{R}$ version 3.2.3.

\section{Results and discussions}

\section{SbS physical and chemical properties}

The physical and chemical properties determined for SbS are shown in Table 1. SbS had intermediate values of density in comparison to wheat straw, which range from 395 to $781 \mathrm{~kg} \mathrm{~m}^{-3}$ (LAM et al., 2008; TUMULURU et al., 2014; SILVA et al., 2019), and higher values when compared to rice straw, which range from 162 to $194 \mathrm{~kg} \mathrm{~m}^{-3}$ (ZHANG; GHALY; LI, 2012). The SbS density was measured with average moisture content of $21.49 \%$ (as seen on Table 1), considered high enough to start its degradation (GOODHEW; GRIFFITHS; WOOLLEY, 2004; BOUASKER et al., 2014). Although SbS degradation analysis was not the focus of this paper, mold formation was observed after a couple of weeks when the residue was collected on the day of the soybean harvest, justifying the need of a preliminary drying.

It was determined that more than $90 \%$ of $\mathrm{SbS}$ extractives were soluble in hot water and did not alter their $\mathrm{pH}$. The T.E.C. amount determined for $\mathrm{Sb}$ was higher than those reported for rice straw (10\%) and wheat straw (7\%) (WORASUWANNARAK; SONOBE; TANTHAPANICHAKOON, 2007; SHMULSKY; JONES, 2019). The SbS A.C. shown in Table 1 is in the range of values $(2 \%-5 \%)$ determined by Reddy and Yang (2009); in contrast to T.E.C., wheat straw and rice straw had higher A.C. than SbS, 6.49\% and $9.2 \%$, respectively (MOUSAVI et al., 2013).

\section{Figure 1 - Edge and face screw withdrawal resistance test}
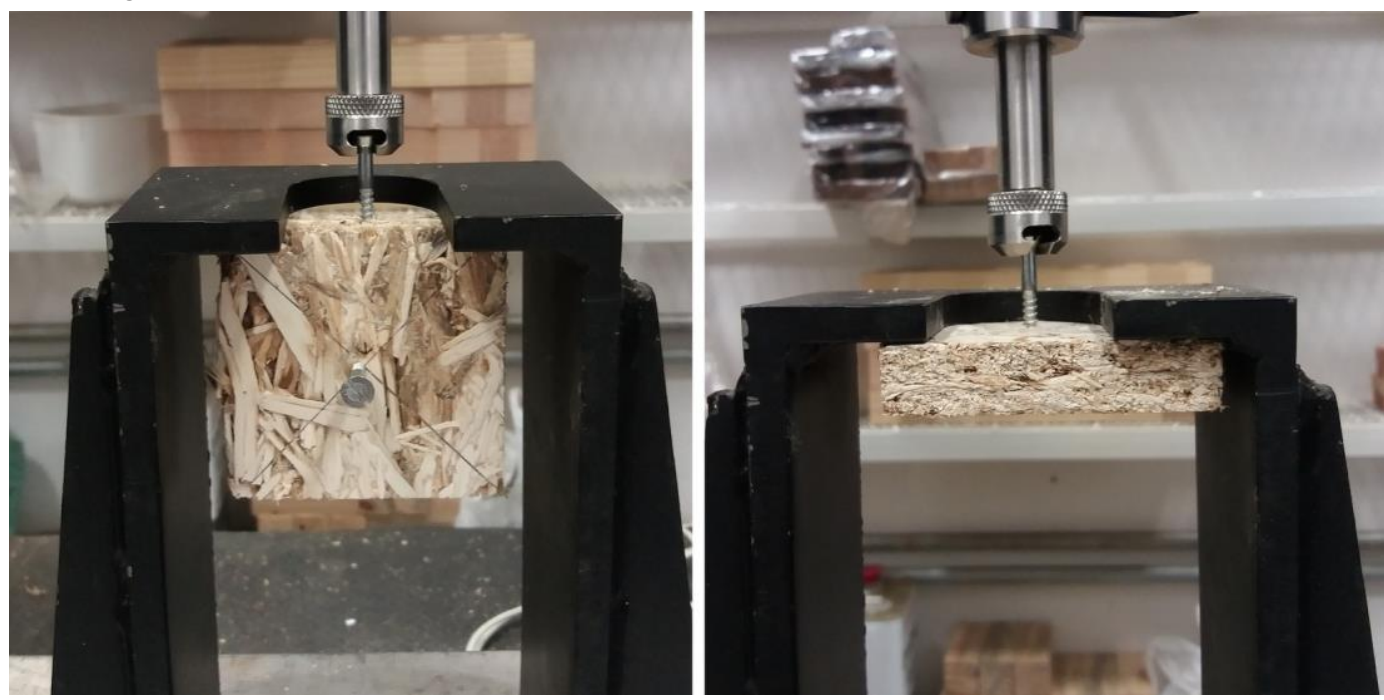
Table 1 - Physical and chemical properties of SbS

\begin{tabular}{l|c|c|c|c}
\hline \multicolumn{1}{c|}{ Properties } & Average & $\begin{array}{c}\text { Standard } \\
\text { Deviation }\end{array}$ & $\begin{array}{c}\text { Coefficient } \\
\text { of Variation }\end{array}$ & $\begin{array}{c}\text { Average Confidence } \\
\text { Interval* }\end{array}$ \\
\hline S.D.** $\left(\mathrm{kg} \cdot \mathrm{m}^{-3}\right)$ & 529 & 65 & 12.37 & $505-553$ \\
S.M.C. $(\%)$ & 21.49 & 3.94 & 18.35 & $20.01-22.96$ \\
T.E.C. $(\%)$ & 12.59 & 0.39 & 3.12 & $11.61-13.57$ \\
H.W.E.C. $(\%)$ & 11.36 & 0.22 & 1.92 & $10.82-11.90$ \\
$\mathrm{pH}$ & 6.96 & 0.07 & 1.04 & $6.78-7.14$ \\
A.C. $(\%)$ & 3.73 & 0.32 & 8.51 & $3.34-4.13$ \\
\hline Note: ${ }^{*}$ < 0.05. & & \\
${ }^{*}$ S.D.: Straw Density; & \\
S.M.C.: Straw Moisture Content; & & \\
T.E.C.: Total Extractive Content; \\
H.W.E.C.: Hot Water Extractive Content; and \\
A.C.: Ash Content.
\end{tabular}

High A.C. usually changes the $\mathrm{pH}$ of the raw material and accelerates the setting of the adhesive, impairing the composite mechanical performance due the reduction of adhesion between the reinforcement and the matrix (IWAKIRI, 2005). This was not likely to happen since SbS had low A.C., compared to rice and wheat straw, and neutral $\mathrm{pH}$ as shown in Table 1, indicating that its chemical properties probably had no negative effect on the OSSB mechanical performance.

The average geometrical dimensions of the soybean stem and petioles are shown in Table 2, as well as the coefficient of variation and the minimum and maximum measured values. It was observed that the soybean stem and petioles differed in almost every parameter measured, except for the total available length. The coefficients of variation were high, indicating a low performance of the adopted procedure.

The number of internodes represents the amount of divisions on SbS that are expected to break during the straw processing for OSSB production. Bach, Domier and Holowach (1999) and Han et al. (2012) describe that a raw material with the least number of internodes (i.e. longer internode length) and a controlled moisture content are desired in order to reduce the generation of fines during the manufacturing process. The effect of these internode divisions is shown in Figure 2 as an irregularity on the OSSB surface, which could difficult or even prevent the successful application of coatings on the board.

Nevertheless, the wide range of results indicates the necessity of a different industrial process than the one applied to wheat straw for the production of OSSB. This can be inferred, as the minimum value obtained of the external diameter is smaller than the maximum value of the wall thickness, due to the variation of the dimensions of the plant along its height. In addition, some plants do not show petioles on harvest season, which are represented by the "zeros" on the number of internodes and on the total available length shown in Table 2.

\section{SbS OSSB physical properties}

SbS OSSB physical properties (i.e. density, moisture content and thickness swelling) are shown in Table 3. OSSB density reached $631 \mathrm{kgm}^{-3}$ in composites produced with $15 \%$ resin content, close to the results reported by Cheng, Han and Fang (2013) and Sitz and Bajwa (2015) for OSSB and MDF (Medium Density Fiberboard) produced with wheat straw and pMDI resin, respectively. The OSSB density increased with higher amounts of polyurethane adhesive content, which can also be observed in Figure 3, where the composition of $15 \%$ shows SbS to be more compacted.

Bertolini et al. (2013) and Varanda et al. (2018) studied wood composites produced with polyurethane obtaining higher densities (from 800 to $1100 \mathrm{kgm}^{-3}$ ). On the other hand, Valarelli et al. (2014) achieved close values to the $15 \%$ polyurethane composition SbS OSSB density in the bamboo particleboard while Chen and Tai (2018) obtained inferior values in bamboo charcoal composites produced with PU adhesive.

The density of the lignocellulosic material used in PU adhesive matrix affects the final density of the composite, so it was expected that SbS OSSBs densities were at least the same of the SbS, but only the $12 \%$ and $15 \%$ polyurethane adhesive content boards were. This was due to the empty spaces caused by the geometry of SbS and the lower compaction of the $6 \%$ and $9 \%$ polyurethane adhesive content treatments, as seen on Figure 2 and Figure 3, respectively. 
Table 2 - Dimensions of soybean stem and petioles

\begin{tabular}{l|c|c|c}
\hline \multicolumn{1}{c|}{ Properties } & & Stem & Petioles \\
\hline Number of Internodes (units) & Average & $15 \mathrm{a}^{*}$ & $5 \mathrm{~b}$ \\
& C.V.** & 14.67 & 93.51 \\
& Minimum & 10 & 0 \\
& Maximum & 19 & 17 \\
Average Diameter $\left(10^{-3} \mathrm{~m}\right)$ & Average & $4.47 \mathrm{a}$ & $2.26 \mathrm{~b}$ \\
& C.V. & 45.01 & 37.87 \\
& Minimum & 0.34 & 0.52 \\
Average Wall Thickness $\left(10^{-3} \mathrm{~m}\right)$ & Maximum & 10.37 & 5.59 \\
& Average & $1.14 \mathrm{a}$ & $0.62 \mathrm{~b}$ \\
& C.V. & 58.92 & 45.79 \\
Average Internode Length $\left(10^{-3} \mathrm{~m}\right)$ & Minimum & 0.22 & 0.18 \\
& Maximum & 4.08 & 1.66 \\
& Average & $4.8 \mathrm{a}$ & $12.7 \mathrm{~b}$ \\
& C.V. & 36.31 & 65.92 \\
Total Available Length $\left(10^{-2} \mathrm{~m}\right)$ & Minimum & 1.0 & 1.0 \\
& Maximum & 11.5 & 32.0 \\
& Average & $76.6 \mathrm{a}$ & $69.8 \mathrm{a}$ \\
& C.V. & 11.31 & 78.26 \\
& Minimum & 56.0 & 0.0 \\
& Maximum & 91.0 & 202.0 \\
\hline
\end{tabular}

Note: ${ }^{*} \mathrm{P}<0.05$

${ }^{* *}$ C.V.: Coefficient of Variation (\%).

Figure 2 - Surface imperfection in OSSB due to SbS internode division (magnification of 100X)

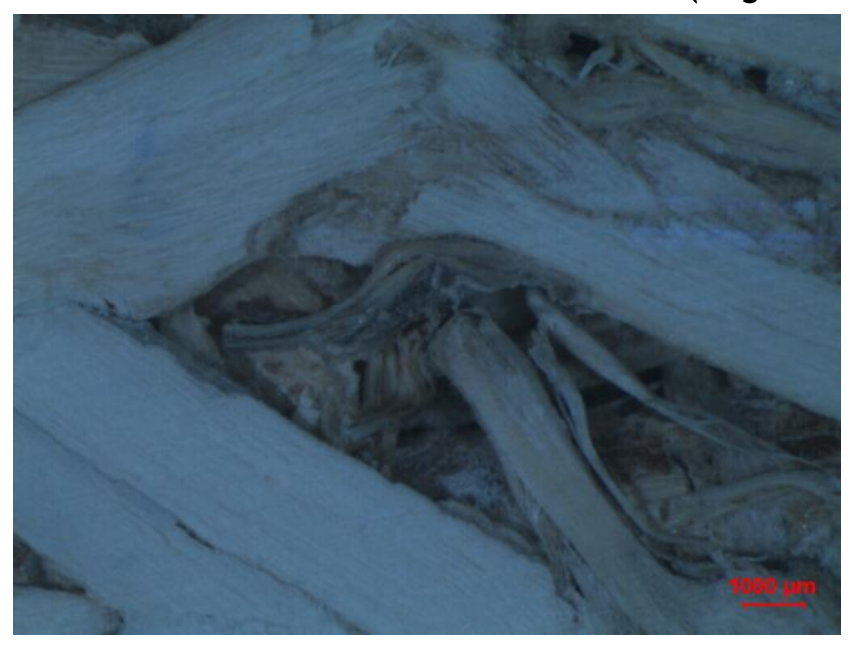

Table 3 - Physical properties of SbS OSSB according to polyurethane adhesive content

\begin{tabular}{l|c|c|c|c}
\hline \multicolumn{1}{c|}{ Properties } & T6* & T9 & T12 & T15 \\
\hline D $\left({\left.\mathrm{kg} \cdot \mathrm{m}^{-3}\right)}^{\text {M.C. }(\%)}\right.$ & $459 \mathrm{a}^{* *}$ & $494 \mathrm{~b}$ & $559 \mathrm{c}$ & $631 \mathrm{~d}$ \\
T.S. $2 \mathrm{~h}(\%)$ & $9.6 \mathrm{a}$ & $9.5 \mathrm{a}$ & $8.8 \mathrm{~b}$ & $8.4 \mathrm{c}$ \\
T.S. $24 \mathrm{~h}(\%)$ & $72.8 \mathrm{a}$ & $52.0 \mathrm{~b}$ & $40.6 \mathrm{bc}$ & $27.6 \mathrm{c}$ \\
\hline
\end{tabular}

Nota: *T6: $6 \%$ adhesive content;

T9: $9 \%$ adhesive content;

T12: $12 \%$ adhesive content;

T15: $15 \%$ adhesive content;

D: Density;

M.C.: Moisture Content; and

T.S.: Thickness Swelling.

${ }^{* *}$ The same letter in the same line signifies that there is not a significant difference among the average values at $5 \%$ of probability. 
Figure 3 - SbS OSSB edge optical microscopies for the four percentages of polyurethane tested (magnification of 100X)
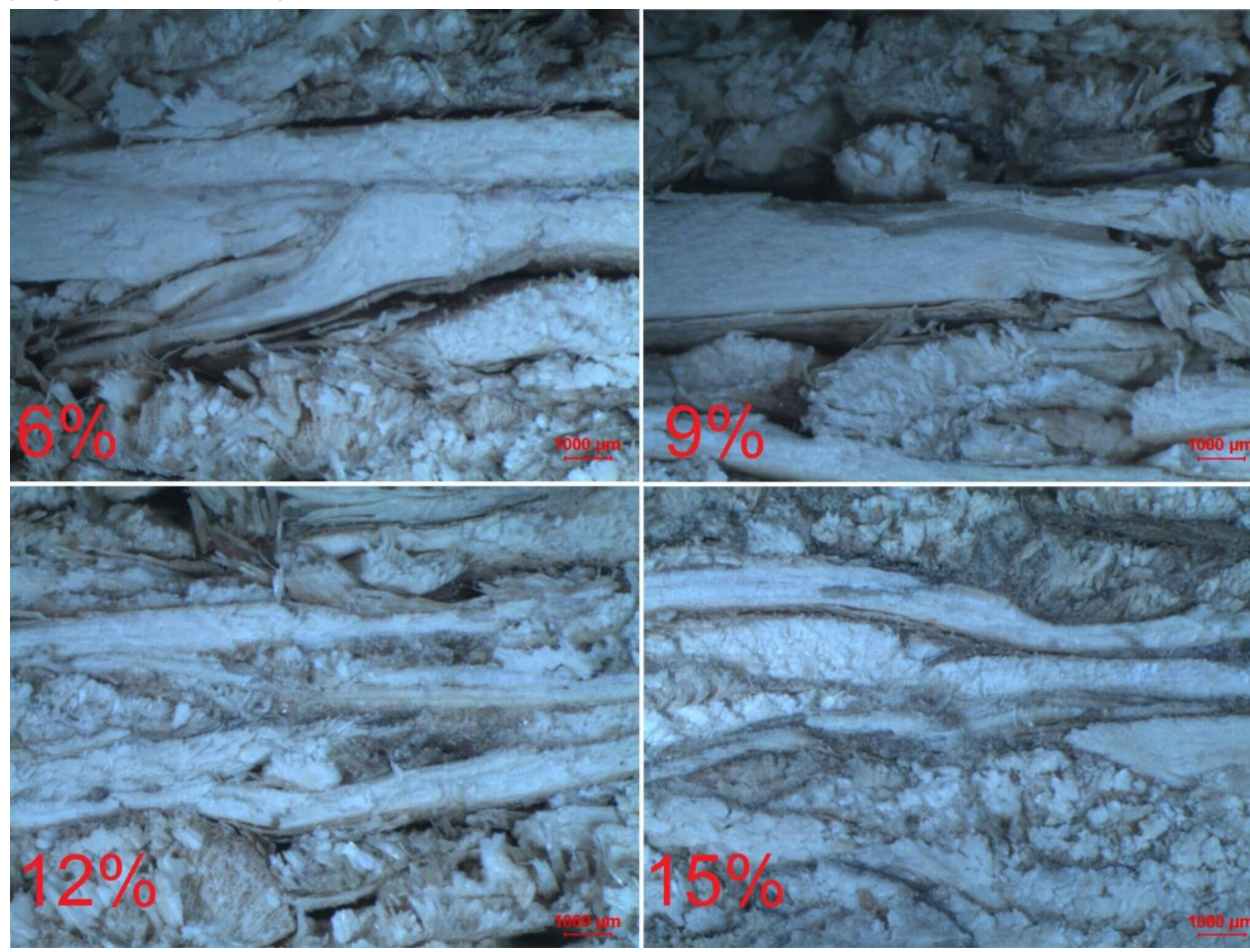

The M.C. determined for all tested OSSB fullfiled the requirements of EN 300 standard (EUROPEAN..., 2006), which must range from $2 \%$ to $12 \%$. The values of M.C. were slightly reduced by the increase of PU adhesive content showing a decrease in water affinity, also observed in the results of T.S. for $2 \mathrm{~h}$ (see Table 3). Nevertheless, over $50 \%$ of T.S. $24 \mathrm{~h}$ was achieved in the first $2 \mathrm{hrs}$ of water immersion and more than $9 \%$ of PU content did not reduce T.S. 24 hrs significantly.

The maximum value allowed for T.S. $24 \mathrm{hrs}$ according to EN 300 standard (EUROPEAN..., 2006) is 20\%, for load bearing boards on dry conditions, less than half the average values obtained for SbS OSSB. T.S. 24h for wheat straw composites - OSSB and MDF - with pMDI binder ranged from $9.2 \%$ to $20.6 \%$ (CHENG; HAN; FAN, 2013; SITZ; BAJWA, 2015); and lignocellulosic particleboards with PU adhesive T.S. 24h ranged from $8.17 \%$ to $22.69 \%$ (FIORELLI et al., 2012, 2013; VALARELLI et al., 2014). The low performance of SbS OSSB is justified due the low adhesion of SbS with PU adhesive, as shown on Table 4 for I.B. tests results.

Specimens showed a thermal conductivity ranging from 0.193 to $0.202 \mathrm{~W} \cdot \mathrm{m}^{-1} \cdot \mathrm{K}^{-1}$, which characterizes this material as a thermal insulator (TRIPATHI; RICE, 2017). Çavuş et al. (2019) determined values between 0.090 and $0.197 \mathrm{~W} \cdot \mathrm{m}^{-1} \cdot \mathrm{K}^{-1}$ in their study with 31 different wood species and Binici, Aksogan and Demirhan (2016) found values between 0.075 and $0.1588 \mathrm{~W} \cdot \mathrm{m}^{-1} \cdot \mathrm{K}^{-1}$ for corn straw boards. The conductivity of SbS OSSB is slightly higher due to its high content of SbS extractives, which probably increased the thermal conductivity despite the low density of the $\mathrm{SbS}$ and the composite.

\section{SbS OSSB mechanical properties}

The static bending $M O E$ and $M O R$ in both directions of the board, internal bonding and screw withdraw tests results are shown on Table 4. SbS OSSB MOE performance did not increase for PU content higher than $9 \%$ of binder was used in its composition and MOR reached its maximum value with $12 \%$ PU, similar to T.S. 24 hr results. EN 300 standard (EUROPEAN..., 2006) determines MOE values of at least $3500 \mathrm{MPa}$ 
and $1400 \mathrm{MPa}$ and $M O R$ values of $18 \mathrm{MPa}$ and $9 \mathrm{MPa}$ in the major and minor direction of load bearing boards in dry conditions, respectively.

OSSB produced with wheat straw and pMDI resin showed MOE of $4000 \mathrm{MPa}$ and MOR of $20 \mathrm{MPa}$ on the major axis, while SbS MDF reached MOE values close to $1420 \mathrm{MPa}$ and MOR of $7.84 \mathrm{MPa}$ as seen on SbS OSSB (CHENG; HAN; FANG, 2013; SITZ; BAJWA, 2015). The low static bending performance of OSSB is due the presence of transversal cracks on $\mathrm{SbS}$ (see Figure 4) which reduced the MOE and MOR values. These fragile cracks were developed because SbS was compressed to form the OSSB, and due to its irregular shape (as showed on the SbS physical and chemical properties subsection) the SbS was bent and twisted (see Figure 3) in the manufacturing process.

The effect of adhesive content of SbS OSSB was clearly seen on I.B. test results, as the $15 \%$ PU content composition performance was significantly higher than the other compositions tested, showing values close to those required for the EN 300 standard (EUROPEAN..., 2006) for load bearing boards in dry conditions. The I.B. performance obtained is also close to other straw based composites produced with $3 \%$ to $4 \%$ pMDI binder and $14 \%$ urea formaldehyde binder (CHENG; HAN; FAN, 2013; BEKHTA; KORKUT; HIZIROGLU, 2013; SITZ; BAJWA, 2015), but inferior to PU bonded composites (FIORELLI et al., 2012 and 2013). The rupture of I.B. specimens occurred on the composite interface (see Figure 5), which created an irregular separation plane due to the heterogeneous dimensions of SbS (described in the SbS physical and chemical properties subsection).

Table 4 - Mechanical properties of SbS OSSB according to polyurethane adhesive content

\begin{tabular}{l|c|c|c|c}
\hline \multicolumn{1}{c|}{ Properties } & T6* & T9 & T12 & T15 \\
\hline MOE major $(\mathrm{MPa})$ & $683 \mathrm{a} * *$ & $1522 \mathrm{~b}$ & $1972 \mathrm{~b}$ & $1943 \mathrm{~b}$ \\
MOE minor $(\mathrm{MPa})$ & $291 \mathrm{a}$ & $537 \mathrm{ab}$ & $498 \mathrm{ab}$ & $626 \mathrm{~b}$ \\
MOR major $(\mathrm{MPa})$ & $3.68 \mathrm{a}$ & $6.95 \mathrm{a}$ & $12.73 \mathrm{~b}$ & $14.48 \mathrm{~b}$ \\
MOR minor $(\mathrm{MPa})$ & $2.37 \mathrm{a}$ & $4.86 \mathrm{~b}$ & $5.12 \mathrm{~b}$ & $3.58 \mathrm{ab}$ \\
I.B. $(\mathrm{MPa})$ & $0.01 \mathrm{a}$ & $0.04 \mathrm{a}$ & $0.07 \mathrm{a}$ & $0.30 \mathrm{~b}$ \\
S.W. on edge $(\mathrm{N})$ & $200 \mathrm{a}$ & $340 \mathrm{ab}$ & $580 \mathrm{bc}$ & $850 \mathrm{c}$ \\
S.W. on face $(\mathrm{N})$ & $490 \mathrm{a}$ & $500 \mathrm{a}$ & $730 \mathrm{a}$ & $1190 \mathrm{~b}$ \\
\hline
\end{tabular}

Nota: ${ }^{*}$ T6: $6 \%$ adhesive content;

T9: $9 \%$ adhesive content;

T12: $12 \%$ adhesive content;

T15: $15 \%$ adhesive content;

MOE: Modulus of Elasticity;

MOR: Modulus of Rupture;

I.B.: Internal Bonding; and

S.W.: Screw Withdraw.

${ }^{* *}$ The same letter in the same line signifies that there is not a significant difference among the average values at $5 \%$ of probability.

Figure 4 - Transversal crack on SbS showed after the OSSB production (magnification of 100X)

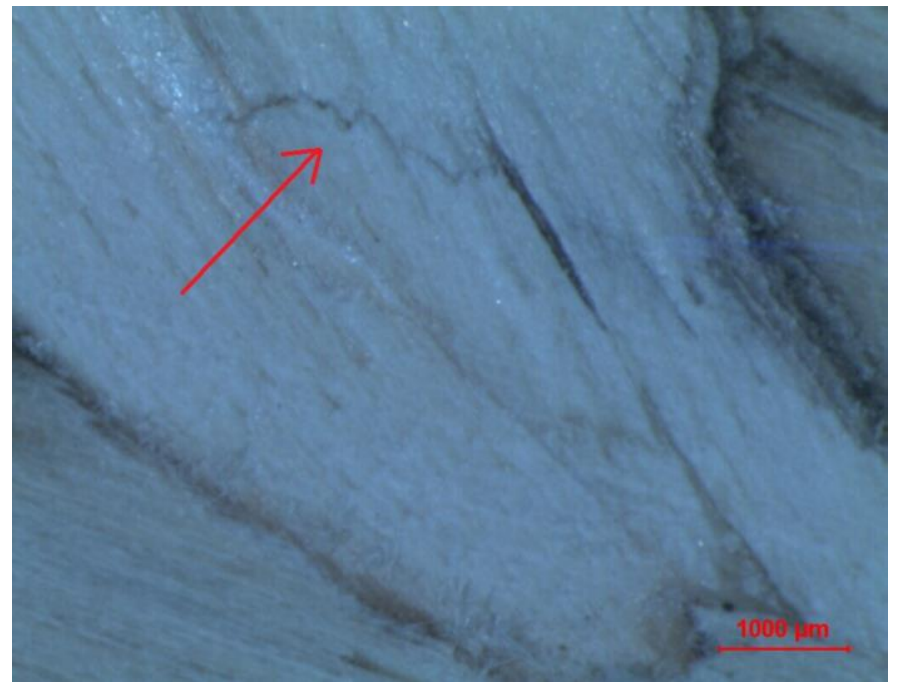

32 Silva, J. V. F.; Silva, M. F. F.; Ferreira; B. S.; Fiorelli, J.; Christoforo, A. L.; Campos, C. I. de 
Figure 5 - Internal bond specimen separated after its failure

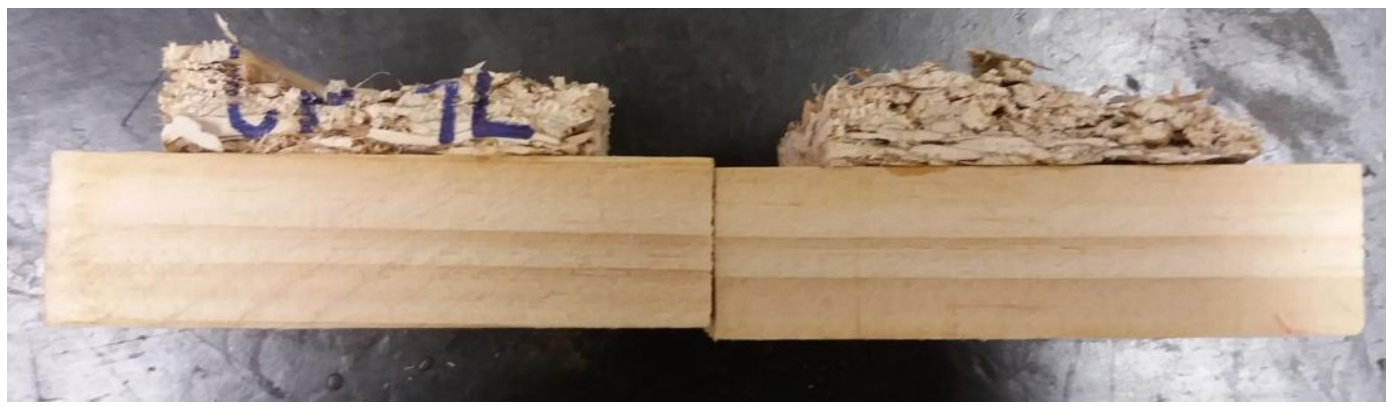

OSSB edge and face $S . W$. strength improved with the increase of PU in its composition reaching values close to the commercially available OSSB (NOVOFIBRE, 2019), although there are no minimum standard requirements for this evaluated property. Sitz and Bajwa (2015) determined the face $S$. W. strength of $164 \mathrm{~N}$ for $\mathrm{SbS} \mathrm{MDF}$, which is inferior to the values obtained in this paper.

\section{Conclusions}

$\mathrm{SbS}$ has heterogeneous dimensions according to its measured parameters, which were: internode length, external diameter and wall thickness. $6 \%$ and $9 \%$ castor oil based polyurethane adhesive content OSSB had lower density than the SbS itself due to the raw material geometry. On the other hand, higher binder content boards (12\% and 15\%) showed a better densification, but developed transversal cracks on SbS due to its irregular shape and the OSSB manufacturing process impairing the boards' mechanical performance.

Some properties of SbS OSSB were clearly affected by the PU adhesive content, such as density, moisture content, internal bonding and screw withdrawal strength, but static bending $M O E$ and $M O R$ and thickness swelling did not improve with higher adhesive content. High SbS moisture content indicates the necessity of its drying before the manufacturing process. Due to the neutral extractives' $\mathrm{pH}$ and the lower ash content it can be concluded that the chemical properties of SbS did not affect the setting of the PU adhesive.

It was verified that the boards exhibited good performance as an insulating material, but not as a structural element. Therefore, they can be applied in construction as vertical or horizontal closing elements.

\section{References}

ADEL, A. M. et al. Microfibrillated cellulose from agricultural residues. Part II: Strategic evaluation and market analysis for MFCE30. Industrial Crops and Products, v. 93, p. 175-185, dec. 2016.

AMERICAN SOCIETY FOR TESTING AND MATERIALS. EN 1755-01: standard Test Method for Ash in Biomass. Philadelphia, 2015.

ARGENTO, R. S. et al. Residuos de desmote de algodón aglomerados: su producción y aplicación en la construcción de viviendas. Ambiente Construído, Porto Alegre, v. 19, n. 3, p. 127-145, jul./set. 2019.

BACH, L.; DOMIER, K.W.; HOLOWACH, R. Method of fabricating a straw panel, board, or beam. U.S. Patent No. 5,932,038. 1999.

BARBU, M. C.; REH, R.; ÇAVDAR, A. D. Non-Wood Lignocellulosic Composites. Materials Science and Engineering, Lausanne, p. 947-977, 2017.

BEKHTA, P.; KORKUT, S.; HIZIROGLU, S. Effect of pretreatment of raw material on properties of particleboard panels made from wheat straw. Bioresources, Raleigh, v. 8, n. 3, p. 4766-4774, 2013.

BERTOLINI, M. S. et al. Accelerated artificial aging of particleboards from residues of CCB treated Pinus sp. and castor oil resin. Materials Research, São Carlos, v. 16, n. 2, p.293-303, jan. 2013.

BINICI, H.; AKSOGAN, O.; DEMIRHAN, C. Mechanical, thermal and acoustical characterizations of an insulation composite made of bio-based materials. Sustainable Cities and Society, v. 20, p. 17-26, jan. 2016.

BOUASKER, M. et al. Physical characterization of natural straw fibers as aggregates for construction materials applications. Materials, v. 7, n. 4, p. 3034-3048, apr. 2014. 
CANGEMI, J. M. et al. Study of the biodegradation of a polymer derived from castor oil by scanning electron microscopy, thermogravimetry and infrared spectroscopy. Polímeros, Rio de Janeiro, v. 16, n. 2, p. 129-135, jun. 2006.

ÇAVUŞ, V. et al. Determination of thermal conductivity properties in some wood species obtained from Turkey. Bioresources, Raleigh, v. 14, n. 3, p. 6709-6715, 2019.

CHEN, Y. -C.; TAI, W. Castor oil-based polyurethane resin for low-density composites with bamboo charcoal. Polymers, v. 10, n. 10, p. 1-12 oct. 2018.

CHENG, W.; HAN, G.; FANG, D. Oriented structural boards from split wheat straw: effects of straw length, panel density, and resin content. Bioresources, Raleigh, v. 8, n. 3, p. 4497-4504, 2013.

EUROPEAN COMMITTEE FOR STANDARDIZATION. EN 300: Oriented Strand Boards (OSB): definitions, classification and specifications. Brussels, 2006.

EUROPEAN COMMITTEE FOR STANDARDIZATION. EN 310: wood-based panels: determination of modulus of elasticity in bending and of bending strength. Brussels, 1993d.

EUROPEAN COMMITTEE FOR STANDARDIZATION. EN 317: wood-based panels: determination of swelling in thickness after immersion in water. Brussels, 1993c.

EUROPEAN COMMITTEE FOR STANDARDIZATION. EN 319: Particleboards and Fiberboards: determination of tensile strength perpendicular to the plane of the board. Brussels, 1993e.

EUROPEAN COMMITTEE FOR STANDARDIZATION. EN 320: Particleboards and fiberboards: determination of resistance to axial withdrawal of screws. Brussels, 2011.

EUROPEAN COMMITTEE FOR STANDARDIZATION. EN 322: wood-based panels: determination of moisture content. Brussels, $1993 \mathrm{~b}$.

EUROPEAN COMMITTEE FOR STANDARDIZATION. EN 323: wood-based panels: determination of density. Brussels, 1993a.

FERREIRA, B. S.; SILVA, J. V. F.; CAMPOS, C. I. Static bending strength of heat-treated and chromated copper arsenate-treated plywood. Bioresources, Raleigh, v. 12, n. 3, p. 6276-6282, 2017.

FERRO, F. S. et al. Painel híbrido OSB/MDP de madeira Pinus taeda e resina poliuretana à base de óleo de mamona. Ambiente Construído, Porto Alegre, v. 19, n. 3, p. 7-14, jul./set. 2019.

FIORELLI, J. et al. Particulate composite based on coconut fiber and castor oil polyurethane adhesive: an eco-efficient product. Industrial Crops and Products, v. 40, p. 69-75, nov. 2012.

FIORELLI, J. et al. Sugarcane bagasse and castor oil polyurethane adhesive-based particulate composite. Materials Research, São Carlos, v. 16, n. 2, p. 439-446, jan. 2013.

GOODHEW, S.; GRIFFITHS, R.; WOOLLEY, T. An investigation of the moisture content in the walls of a straw-bale building. Building and Environment, Oxford, v. 39, n. 12, p. 1443-1451, dec. 2004.

HAN, G. et al. Performance of zinc borate-treated oriented structural straw board against mold fungi, decay fungi, and termites - a preliminary trial. Bioresources, Raleigh, v. 7, n. 3, p. 2986-2995, 2012.

IWAKIRI, S. Painéis de madeira reconstituída. Curitiba: FUPEF, 2005.

KRISNAWATI, A.; ADIE, M. M. Variability of biomass and harvest index from several soybean genotypes as renewable energy source. Energy Procedia, v. 65, p. 14-21, 2015.

LAL, R. World crop residues production and implications of its use as a biofuel. Environment International, New York, v. 31, n. 4, p. 575-584, May 2005.

LAM, P. S. et al. Bulk density of wet and dry wheat straw and switchgrass particles. Applied Engineering in Agriculture, St. Joseph, v. 24, n. 3, p. 351-358, 2008.

LIMA, P. R. L. et al. Efeito do envelhecimento acelerado sobre as propriedades de microconcreto reforçado com fibras longas de sisal. Ambiente Construído, Porto Alegre, v. 19, n. 1, p. 7-20, jan./mar. 2019.

MACEDO, L. B. de et al. Paineis híbridos de lâminas e partículas de madeira para uso estrutural. Ambiente Construído, Porto Alegre, v. 19, n. 3, p. 15-23, jul./set. 2019.

MARRA, A. A. Technology of wood bonding: principles in practice. New York: Springer, 1992. 
MARTELLI-TOSI, M. et al. Chemical treatment and characterization of soybean straw and soybean protein isolate/straw composite films. Carbohydrate Polymers, Barking, v. 157, p. 512-520, feb. 2017.

MERLINI, C.; SOLDI, V.; BARRA, G. M. O. Influence of fiber surface treatment and length on physicochemical properties of short random banana fiber-reinforced castor oil polyurethane composites. Polymer Testing, Essex, v. 30, n. 8, p. 833-840, dec. 2011.

MOUSAVI, S. M. M. et al. Papermaking potential of rapeseed straw, a new agricultural-based fiber source. Journal of Cleaner Production, Amsterdam, v. 52, p. 420-424, aug. 2013.

NASCIMENTO, M. F. do et al. Efeitos das intempéries na rugosidade de painéis de partículas de Pinus sp. Ambiente Construído, Porto Alegre, v. 18, n. 3, p. 227-238, jul./set. 2018.

NOVOFIBRE. Products: novo construction. 2019. Available: www.novofiber.com/products/NOVOCONSTRUCTION.php. Access: 30 jul. 2019.

REDDY, N.; YANG, Y. Natural cellulose fibers from soybean straw. Bioresource Technology, v. 100, n. 14, p. 3593-3598, jul. 2009.

REINPRECHT, Y. et al. Genome regions associated with functional performance of soybean stem fibers in polypropylene thermoplastic composites. Plos One, v. 10, n. 7, p. 1-33, jul. 2015.

SHAO, G. -B.; YANG, P.; JIANG, W. -X. Research and preparation of mycelium-soybean straw composite materials. In: ANNUAL INTERNATIONAL CONFERENCE ON ADVANCED MATERIAL ENGINEERING, 2., Wuhan, 2016. Proceedings [...] Wuhan, 2016.

SHIROSAKI, R. K. et al. Caracterização de painéis de partículas de média densidade feitos com resina poliuretana monocomponente à base de mamona. Ambiente Construído, Porto Alegre, v. 19, n. 1, p. 37-43, jan./mar. 2019.

SHMULSKY, R.; JONES, P. D. Forest products and wood science: an introduction. New Jersey: John Wiley \& Sons, 2019.

SILVA, J. V. F. et al. Characterization of Composite Formed by Cement and Wheat Straw Treated with Sodium Hydroxide. Bioresources, Raleigh, v. 14, n. 2, p. 2472-2479, 2019.

SITZ, E. D.; BAJWA, D. S. The mechanical properties of soybean straw and wheat straw blended medium density fiberboards made with methylene diphenyl diisocyanate binder. Industrial Crops and Products, v. 75, p. 200-205, nov. 2015.

STEFANOWSKI, B. K.; CURLING, S. F.; ORMONDROYD, G. A. Assessment of lignocellulosic nut wastes as an absorbent for gaseous formaldehyde. Industrial Crops and Products, v. 98, p. 25-28, apr. 2017.

TANG, Y. et al. A formaldehyde-free flame retardant wood particleboard system based on two-component polyurethane adhesive. Journal of Applied Polymer Science, New York, v. 108, n. 2, p. 1216-1222, 2008.

TRIPATHI, J.; RICE, R. W. Thermal conductivity values for laminated strand lumber and spruce for use in hybrid cross-laminated timber panels. Bioresources, Raleigh, v. 12, n. 4, p.8827-8837, 2017.

TUMULURU, J. S. et al. Grinding energy and physical properties of chopped and hammer-milled barley, wheat, oat, and canola straws. Biomass and Bioenergy, Oxford, v. 60, p. 58-67, jan. 2014.

UNITED STATES DEPARTMENT OF AGRICULTURE. Oilseeds: world markets and trade. 2019. Available: https://apps.fas.usda.gov/psdonline/circulars/oilseeds.pdf. Access: 30 jul. 2019.

VÄISÄNEN, T. et al Utilization of agricultural and forest industry waste and residues in natural fiberpolymer composites: a review. Waste Management, Elmsford, v. 54, p. 62-73, aug. 2016.

VALARELLI, I. D. et al. Physical and mechanical properties of particleboard bamboo waste bonded with urea formaldehyde and castor oil based adhesive. Matéria, Rio de Janeiro, v. 19, n. 1, p. 1-6, mar. 2014.

VARANDA, L. D. et al. Physical performance of particleboards using Castor oil-based adhesive. Revista Brasileira de Engenharia Agrícola e Ambiental, Campina Grande, v. 22, n. 10, p. 707-712, oct. 2018.

WANG, H. et al. Walnut meal as formaldehyde-free adhesive for plywood panels. Bioresources, Raleigh, v. 13, n. 2, p. 4301-4309, apr. 2018. 
WORASUWANNARAK, N.; SONOBE, T.; TANTHAPANICHAKOON, W. Pyrolysis behaviors of rice straw, rice husk, and corncob by TG-MS technique. Journal of Analytical and Applied Pyrolysis, v. 78, n. 2, p. 265-271, mar. 2007.

ZHANG, Y.; GHALY, A. E.; LI, B. Physical properties of rice residues as affected by variety and climatic and cultivation conditions in three continents. American Journal of Applied Sciences, v. 9, n. 11, p. 17571768, nov. 2012.

\title{
Acknowledgments
}

The authors acknowlegde Capes (Coordenação de Aperfeiçoamento de Pessoal do Ensino Superior - Brazil, code 001), CNPQ (grant \#131765/2018-3, National Council for Scientific and Technological Development Brazil) and FAPESP (grant \#2018/00801-7, São Paulo Research Foundation - Brazil) for financing the development of this study. The authors also thank Mr. Erick Hertel Almeida for providing the soybean straw.

\author{
João Vitor Felippe Silva \\ Departamento de Engenharia Mecânica | Universidade Estadual Paulista | Av. Ariberto Pereira da Cunha, 333, Portal das Colinas | CEP \\ 12516-410 | Guaratinguetá - SP - Brasil | Tel.: (12) 3123-2800 | E-mail: jvf.silva@unesp.br

\section{Maria Fernanda Felippe Silva} \\ Engenharia Industrial Madeireira | Universidade Estadual Paulista | Rua Geraldo Alckmin, 519, Vila N. Sra . de Fátima | CEP $18409-010$ | \\ Itapeva - SP - Brasil | Tel.: (15) 3524-9107 | E-mail: mff.silva@unesp.br

\section{Bruno Santos Ferreira} \\ Engenharia Industrial Madeireira | Universidade Estadual Paulista | E-mail: bs.ferreira@unesp.br \\ Juliano Fiorelli \\ Faculdade de Zootecnia e Engenharia de Alimentos | Universidade de São Paulo | Av. Duque de Caxias Norte, 225, Centro | CEP 13635- \\ 900 | Pirassununga - SP - Brasil | Tel.: (19) 3565-4289 | E-mail: julianofiorelli@usp.br

\section{André Luis Christoforo} \\ Departamento de Engenharia Civil | Universidade Federal de São Carlos | Rodovia Washington Luís, km 235, SP-310 | CEP 13565-905 | São \\ Carlos - SP - Brasil | Tel.: (16) 3351-8262 | E-mail: christoforoal@yahoo.com.br

\section{Cristiane Inácio de Campos} \\ Engenharia Industrial Madeireira | Universidade Estadual Paulista | E-mail: cristiane.campos@unesp.br
}

\section{Ambiente Construído}

Revista da Associação Nacional de Tecnologia do Ambiente Construído

Av. Osvaldo Aranha, 99 - $3^{\circ}$ andar, Centro

Porto Alegre - RS - Brasil

CEP 90035-190

Telefone: +55 (51) 3308-4084

Fax: +55 (51) 3308-4054

www.seer.ufrgs.br/ambienteconstruido

E-mail: ambienteconstruido@ufrgs.br 